\title{
Cultural change in the creative industries: a case study of BBC graphic design from 1990-2011
}

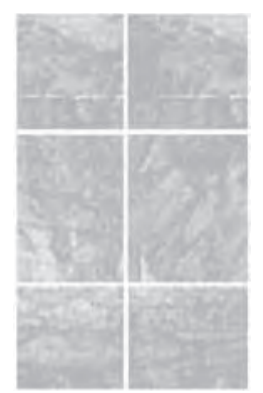

IAIN MACDONALD

Edinburgh Napier University, Scotland

\begin{abstract}
A B STRACT
Using his own experience as a witness and participant in the convulsion that the BBC, and specifically the BBC Graphic Design Department underwent, the author aims to illuminate the cultural change to the creative industries in many advanced industrialised countries that has occurred over the last 20 years. Many industries in the past have undergone similar ruptures and transformations and they will again in the future. The author hopes to draw lessons from an analysis of television graphic design using examples of work that can point out the attributes and skills that a new designer across the globe will need to have and obtain in order to withstand future industrial and cultural changes.
\end{abstract}

\section{KEYWORDS}

graphic design • hybrid production practices • media commercialisation • motion graphics $\bullet$ television public broadcasting

\section{INTRODUCTION}

Over the last 20 years, television graphic design has seen an unprecedented upheaval and transformation in design and commercialisation of practice (Woolman, 2005). Television graphics has gained more screen presence as it has become more affordable and quicker to produce (Ellis, 2002; Holland, 2000). Across the globe the television and communications industries in many advanced industrial countries have adopted the neo-liberalism of the US media system (Hesmondhalgh, 2007; McGuigan, 2004; Sussman, 2002). In the UK, an industry that was once situated within the large broadcasters, such as the British Broadcasting Corporation (BBC), expanded into a rapidly growing community of freelancers and independent design and production companies (Hartley, 2005). With a view to extrapolating to the wider context of the creative industries my aim is to critically explore the perceived 'paradigm shift' 
in the BBC's graphic design sector through ethnographic work that is reflected upon through a body of criticism on cultural institutions. Channel branding is but one small sample of graphic design output on television, yet it is one that has the largest audience, hence the focus of this study when describing the visual changes to broadcasting.

Hesmondhalgh (2007) warns readers and researchers not to look for any easy answers as to why change in the creative industries has happened. Technology has played a significant part in changing the culture of the creative industries: since the 1990s there has been a 'digital revolution' in design (Myerson and Vickers, 2002) and especially in television graphic design (Woolman, 2005). Television graphics that were once made on cardboard and shot on film or studio video cameras are now created electronically on computers using digital painting software. (My first job at the $\mathrm{BBC}$ was to redesign cardboard captions into electronic graphics for Holiday '88.) As generic corporate software solutions have speeded delivery of television graphics across the globe (Wells and Hardstaff, 2008), has it also brought a bland international style? Using examples of BBC graphic design work, I would like to argue that styles of design do not disappear overnight with the introduction of new technology, they multiply and in places merge (Murphie and Potts, 2003). But this is only one of many complex factors that have brought about change in the television industry.

Hesmondhalgh and Baker (2011) examine the working conditions of employment in today's creative industries and they debate the 'good' and 'bad' work within them. They describe the stresses and pressures of cultural workers trying to enter and stay within the creative industries, particularly television. It is the enduring allure of television across the globe that ensures a constant competition for work and the exploitation of new ideas and processes. Many of the interviews in their research chime with my own personal experience as a television graphic designer. But there are few critical commentaries from the makers and creators in the creative industries, in fact there is 'a surprising neglect of these cultural workers in studies on the cultural industries' (Hesmondhalgh, 2007: 308). I aim to make some progress in redressing that neglect with an auto-ethnographic study of this change from the perspective of a television graphic designer, and identify possible attributes needed to survive further challenges.

\section{METHODOLOGY}

I position my perspective as both a designer and a line manager. The duality of my experience at the BBC not only affected my creative practice, but also tasked me with the responsibility of managing other designers to deliver part of this change in design process and commercialisation. This produced at times conflicting emotions, but also a pragmatic approach to managing change. 
To bring further factual, and some additional reflective evidence to my account I have used interviews with colleagues who were leading senior creative personnel and management from BBC Graphic Design and RedBee. The nature of the responses varied because of logistics: Walker's interview was by email, Conrad's by telephone, Wormleighton's interview was face-to-face. I followed many of the approaches advocated by Cohen et al. (2007: 354), such as semi-structured questions, to help enable 'respondents to talk freely and emotionally and to have candour, richness, depth, authenticity and honesty about their experiences'. By engaging in a joint recollection of my memories of the 1990s and comparing it to the situation in 2011, we were able to draw out the differences and similarities. I could also check the accuracy of the activities, procedures and policy to employment, management and design that they described. One interviewee is still working at RedBee after over 20 years' service at the $\mathrm{BBC}$, the others have recently left and now look back in with a more detached perspective. The focus of this research is to qualify my own experience rather than investigate the experience of a large body of people, as in Born's (2005) authoritative ethnographic study of the cultural change within the BBC during the 1990 s.

\section{STRUCTURAL CHANGE: GLOBAL COMMODIFICATION OF CULTURE}

In 1988 I remember the clamour in the BBC Graphic Design department corridors to attend a hastily arranged screening of the rebranded titles for $B B C$ News, designed not by our colleagues in News but by an outside design company: Lambie-Nairn. It was a watershed moment as we came to terms with outside competition. Our gut instinct as BBC designers was to be repelled by the new appearance of $B B C$ News, with imagery that critics described as fascist, strident at best (Lambie-Nairn, 1997). Yet few could deny the bravado of a design that resonated with the BBC's graphic heritage while eschewing the ubiquitous flying chrome typography of the day. Specially filmed projected light effects were digitally composited with striking graphic artwork of lightning bolts emanating from a central spike (see Figure 1). The dark, arguably oppressive graphics of Lambie-Nairn's News rebrand heralded the beginning of a culture clash and the foreboding of increased commercial competition to in-house BBC Graphics. Hand in hand with competition came a culture of 'manageralisation' (McGuigan, 2004).

Organisational restructuring occurred not only at the BBC but also across the whole of the culture industry (Flew, 2005). An ideology of 'managerialization' that had the aim to make management the driving force of a successful society spread from the culture industries to education and other public bodies (McGuigan, 2004). Adorno and Williams share a similar pessimistic view of cultural change across the advanced industrialised world (Jones, 2004). Adorno's work is relevant because his premonition of the 


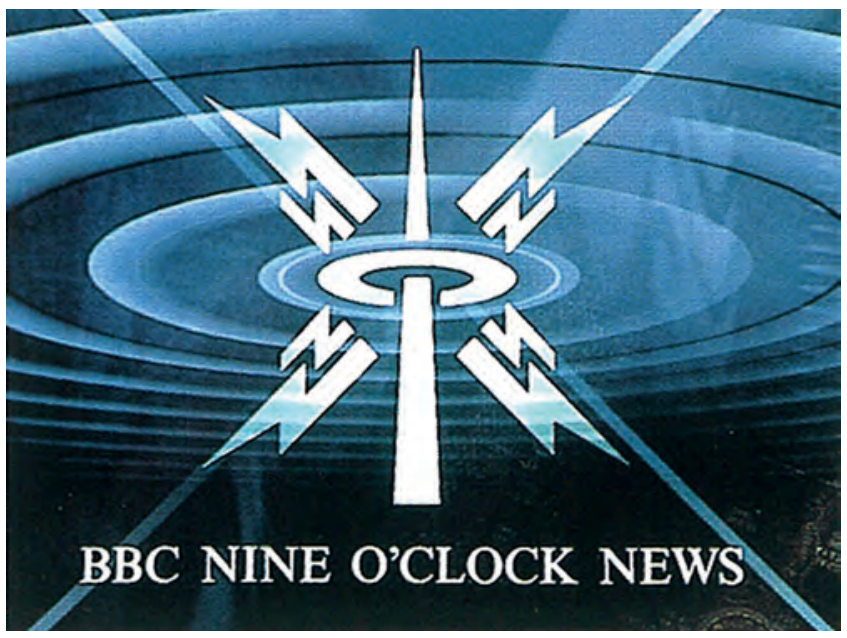

Figure 1. BBC News title sequence 1988 (Lambie-Nairn, 1988). Reproduced with permission.

culture industries appears to have similarities to the highly bureaucratised nature of the BBC, as well as its ideological relationship with mediating culture (both highbrow and popular) to the masses. While some reject Adorno's position that culture would like to be 'untouchable' and free from 'tactical or technical considerations' (Adorno, 1991: 93) as a nostalgic attachment to a pre-industrial form of cultural production, there is an important and continuing interest in understanding the increasing commodification of culture (Miege, 1989).

This commodification of culture is due in part to industrialisation and new technologies, but it can also bring new directions and innovation (Hesmondhalgh, 2007). With a commercialisation of creative services there was also a concern that some skills would be valued more than others, with the possible threat that some heritage and analogue practices could atrophy or be lost altogether. Negus and Pickering (2004: 101) argue that, within culture, tradition can co-exist with modernity, and can challenge the 'binary dichotomies inherited from classical sociology and anthropology' Yet in television the insatiable desire for new technology and consequently new practices suggest otherwise: film editors found their Steenbecks, the large reel-to-reel film editing desks, being replaced by computers with digital editing software to meet the demand of young upcoming programme makers. The BBC's response to technological change was 'on the one hand a highly contentious restructuring, but on the other a commitment to be at the forefront of the digital, multichannel future' (Holland, 2000: 5).

\section{CHANGING PRACTICE：GLOBAL MARKETS}

In the 1990s, BBC branding changed direction away from the digital composition of computer generated (CGI) 3D graphic symbols to a more concrete 
live action image. Across the UK broadcasters, there was an overlap of different branding styles. Lambie-Nairn designed a new BBC2 brand identity in 1991 with a concept centred on different formations of a Gill Sans '2'. Channel branding was now a campaign of different idents, shot on $35 \mathrm{~mm}$ film using traditional analogue model-making crafts and materials, which were then digitally enhanced. In 1997, Lambie-Nairn re-branded BBC1 with similar live action and campaign approaches. Over two years, as many as 59 variations of the yellow and orange balloon globe were filmed across some of the UK's most scenic landscapes (see Figure 2). The iconic BBC globe image was reinvented as something local and national (BBC, 2012). Lambie-Nairn's award-winning work exemplified the broadening scope and ambitions of television graphic designers. While some were becoming slave-to-the-machine ('Paintboxjockeys') others were freed to be live action directors.

But after 2001 when the dot-com bubble burst, the balloon was replaced by a more rooted human image of multicultural performances, some situated again in scenic UK environments (see Figure 3). The BBC1 Rhythm and Movement idents (2002) caused dismay to many viewers by abandoning the BBC globe motif after 39 years on air (BBC, 2012). The dot-com crash had a more devastating effect on the $\mathrm{BBC}$ design workforce, 'a massive downsizing and an end of the old ways' (Conrad interview, 2010). There was 'a major cut in the number of traditional TV graphic designers in London' (BECTU, 2002). The oppositional and alternative groups, those who represented old analogue skills and the commitment to a public service, were made redundant and all vestiges of the old culture and its associated skills were lost, but for a few exceptional designers. What qualities did they have as designers to survive? 'There was a skills divide, and more importantly a mental divide: those who saw the BBC as a job for life, and those who wanted to further their careers'

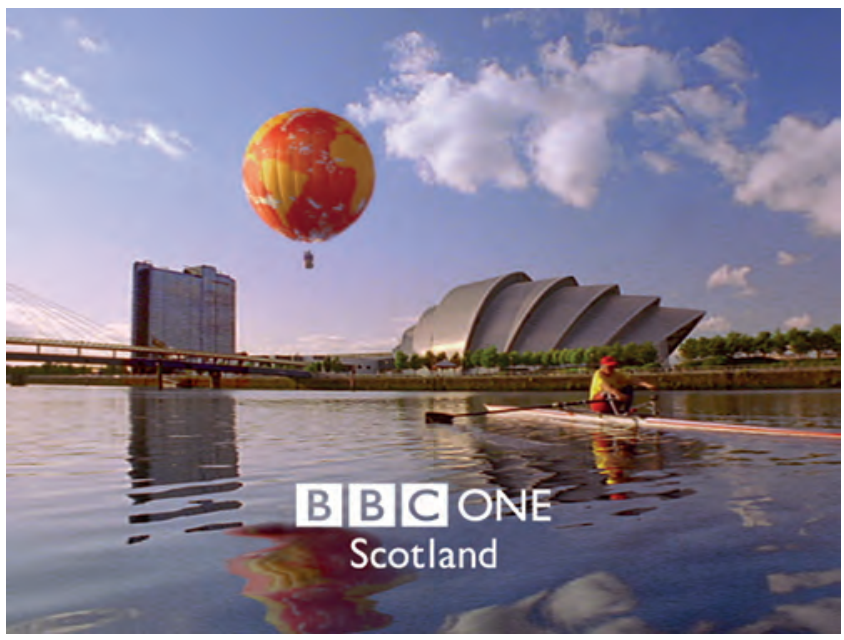

Figure 2. BBC1 balloon globe ident 1997 (Lambie-Nairn, 1997). 


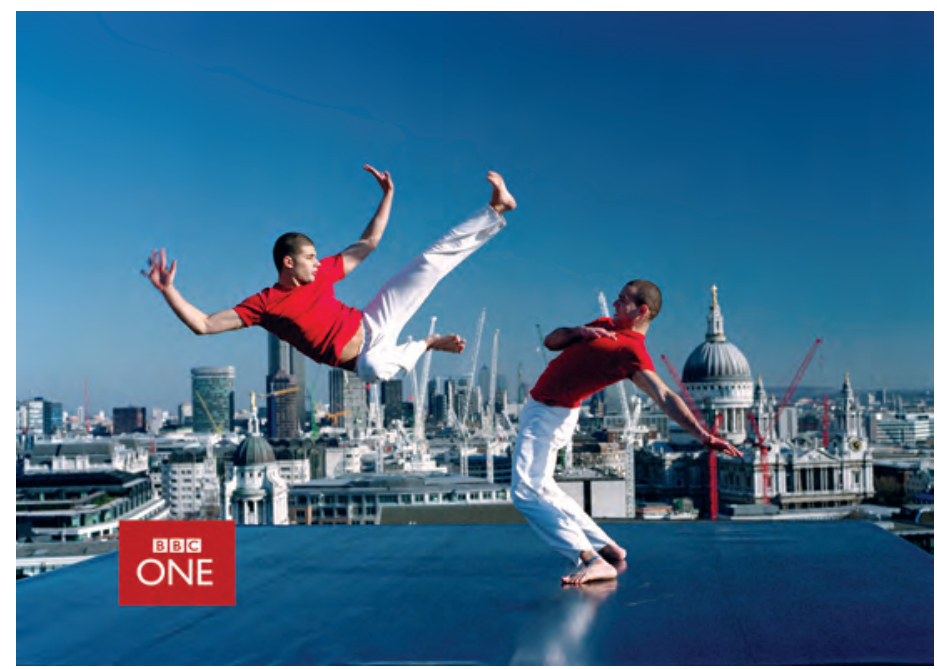

Figure 3. BBC1 Rhythm and Movement ident 2002 (Lambie-Nairn, 2002).

(Wormleighton interview, 2010). A 20-year career as a civil servant in public broadcasting did little to equip a designer for the commercial market, and so many left the industry along with their heritage skills, while a few of those who were made redundant set themselves up as freelancers offering 'traditional tv graphic design' (BECTU, 2002).

For those willing to embrace a freelance digital practice, there was opportunity. As the boundaries between production and postproduction blurred to the point of disappearing, a democratising opportunity was created for individual graphic designers to deliver an entire broadcast quality piece of work on their Apple Mac. Programme makers quickly realised that they no longer had to pay $£ 30,000$ for titles and content graphics because it was possible to do it for a tenth of the price. But for a large and complex business, such as BBC Graphic Design, a business focused on programme graphics alone was now untenable. The department had to look for a new market and so, following the example of arch rival Lambie-Nairn, BBC Graphic Design now focused its business strategy on channel branding, work that commanded considerably bigger budgets and a global outlook. In 2005, after several company reorganisations, BBC Broadcast, and within it BBC Graphic Design, was sold for $£ 166 \mathrm{~m}$ to the Australian investment bank Macquarie (BBC News, 2005).

It is perhaps ironic that BBC Graphic Design was launched as RedBee with a commission for the rebranding of ITV already in production. Perhaps confirming a creative orthodoxy in UK terrestrial channel branding, the design approach fused live action scenes that revealed a bold graphic band and logo (see Figure 4). The optimistic gold colours of ITV seemingly proved that rebranding could significantly improve business performance with a run of award winning work. RedBee became a member of 'the design companies 


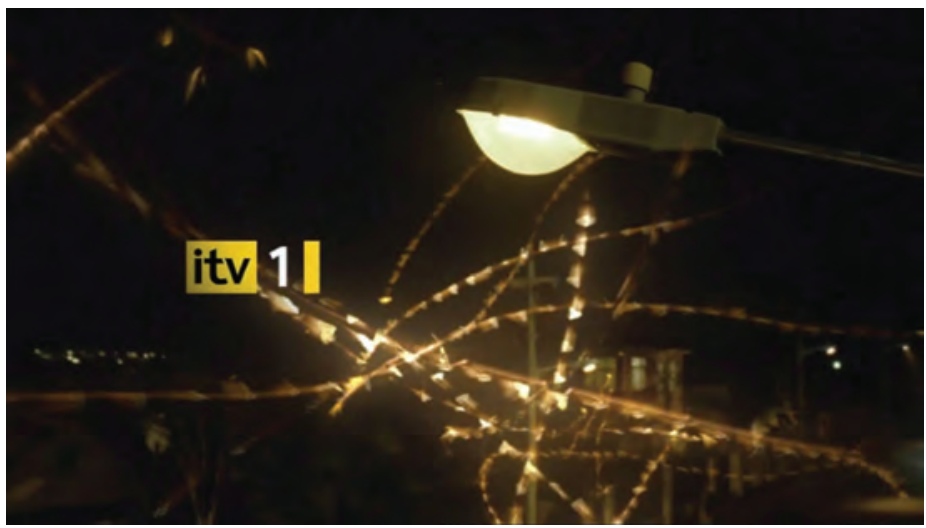

Figure 4. ITV ident 2005 (RedBee, 2005).

super league, ranked 4th in Design Week's Top 100 Design Groups survey in 2007 (Design Week, 2007). Turnover in 1996 was $£ 2 \mathrm{~m}$; by 2008 it was $£ 14 \mathrm{~m}$, most of it non-BBC (Conrad interview, 2010). It did not come overnight, new talent had to brought in and old talent had to be retrained or managed out.

In 2000, Jeff Conrad joined the Graphic Design department from BBC Post Production where he had a marketing role, to become Head of Design at RedBee until 2010. As an outsider with a recent post-graduate qualification in marketing he was able to view the business from a different perspective and was sufficiently detached to drive through unpopular restructuring. With the help of a consultant, Conrad began to change the business from an in-house provider to a more commercial operation.

We introduced a strategic planning division with media planners, a client engagement team who wrote the creative brief for the designers, which pushed design further. A $£ 500 \mathrm{k}$ project required a lot more research and substance than a storyboard. (Conrad interview, 2010)

To win work you need compelling ideas: 'good ideas spring from inspirational briefs - if you don't get one from the client you need to create your own. And actually clients don't often know how to react to creative work' (Walker interview, 2010). While most professionals place conceptual skills and ideas above the mastery of machines (Cooper in Woolman, 2005; Lambie-Nairn, 1997), business skills and client relationships are also critical. A new role of Creative Director was created in 2002 as a bridge between the creative community and management, and between big clients and creatives.

Advertising and planning people have changed the working practice: brands now have structure, we understand them rather than just delivering something that just looks good. It is the cross over from advertising to broadcast that has made a difference. (Wormleighton interview, 2010) 
This was a structure and business model that was pioneered in television graphics by Martin Lambie-Nairn, widely regarded to be the first graphic designer to 'transplant the creative research and planning techniques of advertising agencies to television presentation departments' (Myerson in Lambie-Nairn, 1997: 14). When RedBee won the rebrand for BBC1 (2006) and BBC2 (2007) it was a significant turning of the tables (see Figure 5). The image exuded the confidence and technical excellence graphic designers now showed as conceptual thinkers and live action directors. A central concept was again exploited in a campaign of visually varied scenarios. A circle was all that remained of BBC1's iconic globe identity of the past. Live action and CGI blended into sophisticated digital manipulations that were only matched by those of another terrestrial competitor: Channel 4 . UK television graphic design had world-leading conceptual excellence, matched in its quality of art direction and breadth of campaign planning across a multimedia of platforms: broadcast, online and on-demand.

The few remaining original BBC designers had reinvented themselves by embracing new commercial business practices that had inflicted painful restructuring, but they were now beating the independent design companies at their own game. Prestige had returned within the department, but at a cost to what Williams (1981) describes as the 'alternative' and 'oppositional' groups - the part of the workforce that remains attached to older cultural practices. RedBee's reach had become global to the point that in 2010 it was disqualified from the Design Week survey, which now viewed RedBee as a global rather than a UK company (Design Week, 2010).
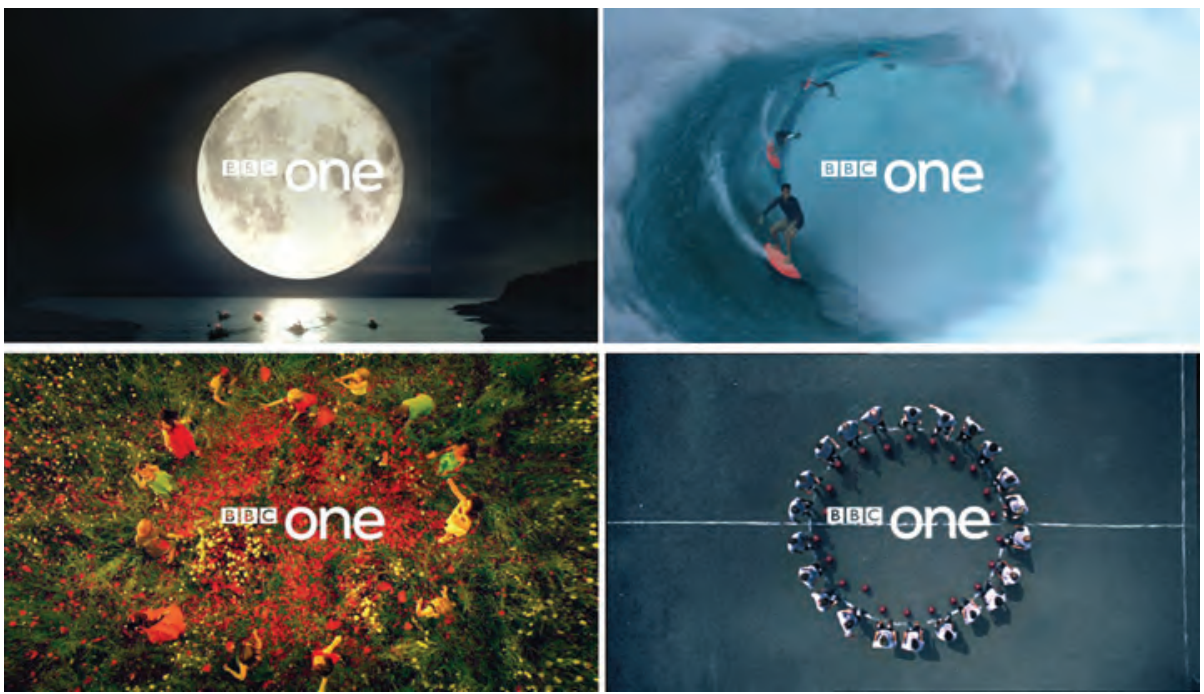

Figure 5. BBC1 idents 2006 (RedBee, 2006). 


\section{TECHNICAL CHANGE: 'PENCIL TO PIXEL'}

'Technical changes were the easiest of the two driving forces to embrace. It made production processes quicker and easier' (Conrad interview, 2010). Conrad's opinion and recollection mask the complexity of the broader external socio-political factors already discussed, but also the historical continuum of changing creative production technologies (Flew, 2005).

In television production it is commonly regarded that the greatest technical change was from analogue to digital (Myerson and Vickers, 2002). But it is only one in a series of changes that have affected graphic design in television. Even in the 1960s there was friction between differing technologies, true to Williams' (1981) cultural model.

The BBC Graphic Design Department in the mid-Sixties was a world leader in the craft of television design and employed the very best people in the industry. There was however a great deal of friction between two distinct camps. The old guard from the Ealing Studios era of caption writing, maps and hand lettering, bitterly resented the new generation of graphic designers; they called us 'Letraset designers'. (LambieNairn, 1997: 43)

With the start of colour broadcasting in 1969, the 'Letraset designers' embraced improved quality and increased aesthetic range. In the early 1980s, television faced another fundamental upheaval with the introduction of computers in rostrum cameras and mainframe computer generated imagery (see Figure 6): 'many were baffled, shocked but could see its immediate benefits with increased production speeds' (Lambie-Nairn, 1997: 43). While some were concerned that increased productivity would lead to less staff, in fact it had the opposite effect. The faster production times and the relative ease of creating graphic collages with a new pristine and textural surface led to an increase in demand. Ellis (2002) sees the speed of audiences' acceptance for more graphic imagery as much a motivator as the designers' desire for new tools. Suddenly every television producer wanted graphics to make their programmes look modern and watchable. 'Graphics departments gained a new prestige' (Holland, 2000: 106) as they moved 'from the wings to the centre stage' (Taylor in Merritt, 1987: 42).

Analogue and digital processes intermingled and overlapped. As a new young digital designer I worked amongst older designers experienced in analogue film and we learnt from each other. The best of the first BBC generation - Alan Jeapes, Graham McCullum and Bernard Lodge - all readily welcomed new technology and exploited it to push their ideas and designs further than would have been possible before. While, like craftsmen, they embraced a bricolage of heritage techniques, at the heart of their work would be an idea, a core reason for using such a technique following the form and function modernist training of their era. After leaving the BBC to work in higher education Colin 


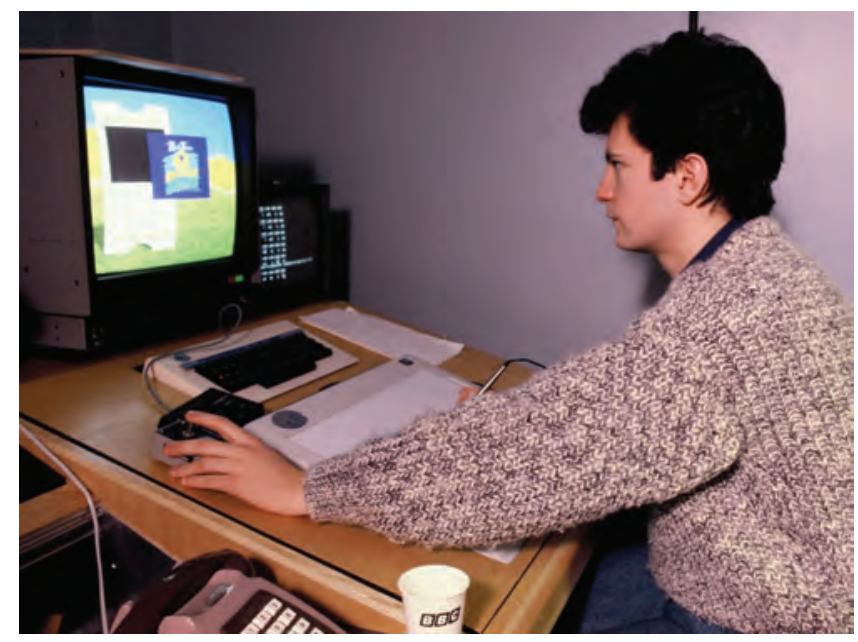

Figure 6. BBC graphic designer using Quantel Paintbox 1988. Photograph: lain Macdonald.

Cheesman, and later Liz Friedman, continued to make a significant contribution to the visual change of television graphics through the following generations of designers that they taught. For many young designers of the postmodern age, there was the allure of new digital techniques to 'constantly pressure the designer into the temptations of movement and surface gloss as a solution to every problem' (Crook in Merritt, 1987: 45).

In the mid-1990s, it appeared to many British and American academics writing in Emigré and Eye, that the very meaning of graphic image and text was changing with a new digital language. Clichés like page turns, green grids, flying chrome letters, pictures within pictures, hierarchies of layers created a 'bland international look' (Merritt, 1987: 14). Basic drawing skills became irrelevant when design degenerated into selecting software effects. Television graphics could be described as moving towards postmodernism as the trend became increasingly multilayered and self-referencing, what Eco (1985) calls 'intertextuality':

Television graphics have a built in stylistic appetite for images. Because of this graphic appetite, images are transformed from the world of illusionistic realism into a frenetic world of spinning surfaces. Television is not just a succession of images or shots. It is a machine that consumes images within its own images. (Caldwell in Ellis, 2002: 97).

Caldwell is following Baudrillard (1987: 28) in this respect: 'the exponential enfolding of the medium around itself ... this endless enwrapping of images (literally, without end, without destination) which leaves images no other destiny but images', especially in television news programmes. The titles for news satire The Day Today (1994) parodied every graphic cliché with a CGI visual 
pomposity that matched its presenter Chris Morris and supporting signature tune. While Ellis argues that the television graphic is a 'working over, placing and processing of the witnessed fragments of the real' this may well be true of news graphics but, in the context of the opening title and brand identities, they were very much postmodern in their 'act of referencing cultural styles or tailoring messages to narrowly defined communities' (Lupton, 2008: 8). Layers and transparency hierarchies can suggest conflict or synthesis of ideas, and they have always been at play in the graphic arts, it is just that today's software makes them omnipresent and a generic graphic language (Wells and Hardstaff, 2008). Dauppe (1995: 74) argues:

Conventions of televisual language derive from previously existing technologies and media, despite the arguments to the contrary which state that it is a new 'pure' form ... Typography on television, though a moving image, is still firmly rooted in the conventions of print and book culture.

In the late 1990s, there was suddenly a greater democracy of creation as moving image and graphics technology became more affordable: a Mac with software was a hundredth of the price of a Quantel editing system. It also offered designers the resources to make their own films with 'a new visual language' (Myerson and Vickers, 2002: 310). The 'epoch-making shift to digital technology meant that designers and art directors had to rethink the very core of their practices' (p. 298) but are there traditional practices that have prevailed? There was also an emergence of the creative industries discourse, which allowed a re-imagining of cultural production within the economy and its relation to cultural policy (McGuigan, 2004). As more content is produced by free labour, Hesmondhalgh (2010) argues that it has changed the professionalism of the industry. The debate will continue on how to open up creative autonomy, while reducing and eliminating the negatives of inequality and social injustice within the cultural industries. What are the attributes that graduates must develop to succeed in the creative industries?

\section{THE NEW DESIGNER: A NEW BRICOLEUR?}

In light of the discourse of the creative industries and its emphasis upon the rather ambiguous traits of 'creativity' (Adorno, 1991; Hesmondhalgh, 2007; Williams, 1983) it is important to consider the necessary attributes that a new designer should have. What pedagogies need to be either developed or reinforced to ensure the continuing success of the creative industries? Education is now trying to address the concept of lifelong learning in order to prepare workers to be adaptable and re-trainable for changing global markets and technologies (Facer, 2011). Within design there has long been a desire for new and innovative processes that will stimulate imaginative problem solving and produce original thinking. But it is often not a linear path, because as one new 
style or approach becomes ubiquitous there are often fractional groups that find a resurgence as designers take a postmodern twist on processes, which can result in a renaissance of specializing groups with older craft skills (Wells and Hardstaff, 2008).

There is a line of thinking that brings the ideas of Lévi-Strauss to graphic design. Louridas (1999) makes an argument for 'design as bricolage', and he uses bricolage(using whatever materials are available) as a metaphor for understanding the design process. I would like to suggest that the metaphor of a bricoleur as described by Louridas, could be applied to the new designer in motion graphics. This does not contradict the essence of designers who can respond imaginatively and creatively with their materials, defining and deconstructing problems, 'to understand the occasion, the execution, and the purpose of [their] activities' (p. 534); although this is in contrast to Jones (2004), whose reading of Lévi-Strauss is that bricoleurs operated within a Kantian unconsciousness and so were 'not the authors of their actions' (p. 110). Instead I will argue that a bricoleur can embrace a plurality of production approaches by combining traditions of the past with new technologies, and communicate with an originality that can break down the formalist approach of modernism.

As a teenager interested in graphic design, I was drawn towards television because it embraced new digital computer technologies: it was dynamic and animated, it represented the future. Perhaps like many others I was also 'seduced' by 'the subliminal thrill of knowing that perhaps millions will see [my] work in a single moment' (Millar in Merritt, 1987: 14). Hesmondhalgh and Baker (2011) argue that, in the current economic climate, to gain entry into the creative industries is so competitive that it requires 'self-exploitation', which is characterised by long hours, acceptance of little or no pay and job insecurity. When new talent is recruited into a department, or company, it brings a fresh input of energy and, because graduates already have a developed appetite to learn, they can quickly assimilate new practices and technology. But it is important to assess their attitude because, as Williams (1983: 133) warns, there are also phases of 'settlement', a normalized working practice, 'in which formerly innovating technologies have been absorbed and only the currently new forms are a threat'. Today's innovators could be tomorrow's luddites. It is critical then to inculcate the value of a pluralistic approach, one that is willing to explore the potential of new technologies yet recognise the traditions of heritage processes.

While it has already been argued that new technology allows for more individual expression, both Jane Walker, ex-RedBee Senior Creative Director, and Ian Wormleighton, Red Bee Creative Director believe that rather than being a 'brilliant recluse' new designers must also be more collaborative and willing to learn from others as well as being 'self sufficient'. New designers are expected to be 'plugged in' to current trends and the culture around them, and not just by proxy through the internet. The experience of seasoned designers and the creative energy of youth are recognised as important ingredients in building project teams. 
Older designers are always catching up with technology but are great with ideas. New guys go straight to production before crafting an idea. So the best way is to mix them together in teams where they crossfertilise and learn from one another. (Walker interview, 2010)

It could be argued that, as a result of different eras of art school training, a young digital designer may let the surface look take precedence over an idea, whereas an older designer may be stronger conceptually but less technically adept digitally. I would argue that this may have been the case during the transitional period between analogue and digital in the 1990s, but far less likely in 2012 now that older practising designers have assimilated digital software and have become proficient in them. Walker insists that analogue technology and traditional artistic skills have a role: 'more than ever - as reaction against virtual creation - touched by human hand, personal, tactile, quirky, unique' (Walker interview, 2010). Otherwise an approach reliant on generic software effects creates bland and clichéd graphic design. A hybrid of digital and analogue skills is therefore essential to the future of design.

The new designer must then have a pluralistic approach to processes, but how are these processes evaluated? The bricoleur interrogates the tools available, assesses and reviews. There is a dialogue with the materials where there will be contingencies that limit the scope of the design: either budget, availability or an external influence from the client. The selection of materials is as important as the form of the outcome. The process of reflection is hermeneutic and develops an iterative understanding of the design work (Barone and Eisner, 2011; Carter, 2004; Dewey, 1979[1934]; Elkins, 2009; Schon, 1987; Sullivan, 2010). Louridas (1999: 520) argues that this conversation begins through 'design-by-drawing', where a 'metaphorical bricolage' is made to visualize and interrogate the problem. 'Bricolage is the creation of a structure out of events.' Maylin Gouldie's storyboards for her BBC2 idents reflect the immediacy of her drawing to communicate the dramatic sequence of the visual effects on screen (see Figure 7). Her drawings explore the different angles and developing intensity of the sparks to communicate a graphic narrative in the brief seven seconds of animation.

When there is no technology at hand, an idea is all a designer has to rely on, as Lambie-Nairn (1997: 61) attests: 'The technology itself does not matter. What is important is the design idea; technology is simply a tool to help express it, a means to an end.' Critical thinking and drawing skills are the attributes that design companies, such as RedBee, look for when recruiting new designers. Ideas are primary: 'there is a technical expectation, but people are employed for the strength of their ideas' (Wormleighton interview, 2010). But in order to express those ideas, traditional skills of drawing, skill and knowledge of typography and lettering are just as relevant today as in 1990 and indeed since television graphics began. Wormleighton clearly differentiates creative talent by craft skills: 'the best people we have are really good 

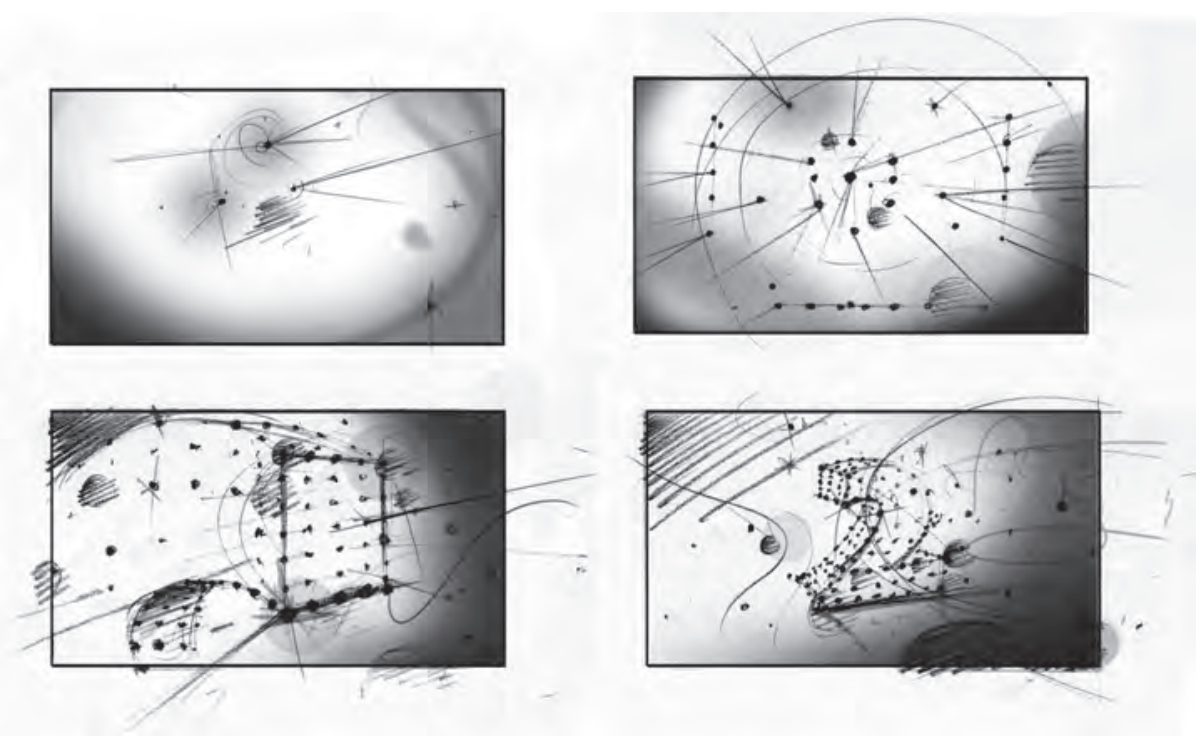

Figure 7. BBC2 ident storyboards (Maylin Gouldie).

crafts people who can draw, you could take away their Mac and they could still create something' (Wormleighton interview, 2010). It is important for the new designer to take the attitude of a bricoleur, as they will need an ability to adapt and change to new technical innovations and processes, while nurturing and practising their craft skills. But as television graphic design has become more aligned to advertising, presentation is just as important as design. In order to communicate the value of an idea and branding strategy, presentation skills are more critical than ever.

What are the pedagogic structures to train and develop staff within these creative industries? In the BBC, some provision was made in 1990s for software training, but for many thereafter it was more about learning on the job. To be successful, maintain employability and to endure the constant change in the motion graphics industry you must have 'driving curiosity, flexibility, adaptability, and the courage to say, "I don't know how to do that ... but I'll find out"' (Pite, 2003: 299).

Learning itself is 'just-in-time', outcome-orientated, continuing, selfmotivated, and self-monitored, and increasingly sought from commercial learning services rather than from traditional certification institutions with disciplinary silos and a provider mentality. (Hartley, 2005: 25)

If Hartley's assessment is correct, it places pressure on art colleges and universities where the range of media platforms is increasing and the traditional design boundaries are blurring. 
It is likely that there needs to be pedagogical development or evolution to mirror changing professional and production modes, but it is clear that the philosophical foundation of educational or professional facilitation ought to establish creative principles that make skill transfer and cross-contextual play natural. (Wells and Hardstaff, 2008: 19)

Wells and Hardstaff (2008) insist on a critical approach to technique and creative learning, a balance of theory and practice that allows for the development of interdisciplinary approaches and critical thinking: a postmodern bricolage. Yet those in industry can often see education only from the point of view of answering their specific needs rather than those of the designer.

This can mean that the design skills covered in a course are wide and varied. Many graduates have multi-platform skills, but not the depth of knowledge they'd have from studying just one discipline. The training curve for motion graphics can be steep when graduates join us. (Conrad in Computer Arts, 2007)

Those within the profession and some academics have called for a return to the basics (Woolman, 2005). The leading designers of the 60 s to the 90 s, like Lambie-Nairn, all had a modernist training (Lambie-Nairn, 1997). Lupton (2008) argues that the modernist Bauhaus approach still has a role to play in academic design teaching. Educators at the Bauhaus saw that art and design were being transformed by technology, yet their ideas remained humanistic. Design could not be reduced to its function or to a technical description.

Rowe (1978) and Louridas (1999) argue that by assuming the role of bricoleur it is possible to negotiate the problems associated with modernism. I argue that we seek to embrace a pluralist approach that accommodates the sleek and perfected solutions but also the sublime accidents, the contaminated and the hybrid. If this sounds like a counter-culture it is one that Wells and Hardstaff (2008) believe is already compromised by the acceptance of the term 'motion graphics' as a new label that drops 'design' (one coined by the computer animation pioneer John Whitney in 1960): the removal of design exposes a process that places 'an over-reliance upon corporate software to deliver message-free, 'content-lite' material' (Wells and Hardstaff, 2008: 52).

The bricoleur may offer a metaphor for not just the new designer but the surviving established designer, one who can take a postmodern approach to motion graphics, and perhaps this could be applied across the creative industries as a whole. As a 'cultural intermediary' (Adorno, 1991; Bourdieu, 2000; Featherstone, 1991), the bricoleur can not only communicate as a taste-maker between manufacturers and the public, but also retain a counter-culture producing work in other media and arenas that are free of the 'high administration' of corporate culture industries. It is in the independent spaces of music, film and installation that the postmodern omnivore can 
find individual expression, to explore the avant-garde that forms the taste of tomorrow. Design groups Why Not Associates and Tomato have each contributed greatly to the changing appearance of television graphics through these independent spaces. Rather than follow a corporate company appearance like Lambie-Nairn, their strategy is to work more as an artistic design co-operative or group.

Yet there is also a remnant of modernist thinking that also inhabits the bricoleur approach, one that seeks to be authentic and speak through the design (Louridas, 1999). In a mediated world, the idea of what is authentic is a paradox, for while it may be created with a craftsman's honesty, its mediated presence can only give the appearance of such authenticity (Baudrillard, 1987).

\section{CONCLUSION}

When the BBC Graphic Design department was set up in 1954, it was at the dawn of television, an exciting new media that followed a very British approach to production. Today RedBee's website refers to a similar 'uncharted media landscape' (RedBee, 2011) where its core business is connecting with viewers, but now on multiple platforms - globally. Technology and its development have undoubtedly had a hand in the form and content of motion graphics, but as Benjamin (1992) argued in 1936, the modern experience also shapes the organisation of the makers and the users.

The aim of this article has been to take the BBC as an example of the modern experience, a convulsion that has affected many creative industries in the industrialised Western capitalist democracies since 1990. The effect of neo-liberalist policy on the organisation of working practices and management within BBC Graphic Design is but one example of how economic reasoning can affect real lives. The scarcity of such critical commentaries from makers and creators in the creative industries and the recent questioning of the economic value of creative education by government suggest that there is urgency to this prescient concern.

An historical analysis provides evidence that change in industrial production processes is not new and it will continue so long as there is a demand for creating new cultural products, artifacts and experiences. There is a danger that creative industries can forget the lessons of the past, and that experience is devalued in cost cutting measures in an attempt to make the workforce more economic. The role of the designer can be seen as a bricoleur, not simply to solve a problem as a scientist might, but to enrich our experience of life, humanise it with a sense of enjoyment and pleasure by using materials that lie within a tradition (Louridas, 1999). Tradition is like a bridge that is continually being built but never reaches the other side: a 'bridge between memory and imagination' (Negus and Pickering, 2004: 104). This can only happen if the mark of the designer is evident and not lost in the shallow generic software solutions that digital technology provides. 


\section{F U N D I N G}

This research received no specific grant from any funding agency in the public, commercial, or not-for-profit sectors.

\section{REFERENCES}

Adorno, T. (1991) The Culture Industry. London: Routledge.

Barone, T. and Eisner, E. (2012) Arts Based Research. London: Sage.

Baudrillard, J. (1987) The Evil Demon of Images. Sydney: Power Institute Publications.

BBC News (2005) BBC Broadcast sell-off approved. Available at: http:// news.bbc.co.uk/1/hi/entertainment/tv_and_radio/4708749.stm (accessed April 2012).

BBC (2012) The BBC logo story. Available at: http://www.bbc.co.uk/ historyofthebbc/resources/in-depth/bbc_logo.shtml (accessed April 2012).

BECTU (2002) Job cuts in BBC Graphics. Available at: http://www.bectu.org. uk/news/bbc/nb0168.html (accessed April 2012).

Benjamin, W. (1992) Illuminations. London: Fontana Press.

Born, G . (2005) Uncertain Vision. London: Vintage.

Bourdieu, P. (2000) Distinction: A Social Critique of the Judgement of Taste. London: Routledge.

Carter, P. (2004) Material Thinking: The Theory and Practice of Creative Research. Melbourne: Melbourne University Press.

Cohen, L., Manion, L. and Morrison, K. (2007) Research Methods in Education, 6th edn. London: Routledge.

Computer Arts (2007) Profile: Red Bee. Available at: http://www.computerarts. co.uk/in_depth/interviews/profile_red_bee (accessed April 2012).

Conrad, J. (2010) Recorded interview by author on 29 November.

Dauppe, M. (1995) Turning on to television. In: Triggs, T. (ed.) Communicating Design: Essays in Visual Communication. London: BT Batsford, 68-74.

Design Week (2007) Jockeying for position. Available at: http://www. designweek.co.uk/news/jockeying-for-position/1135543.article (accessed April 2012).

Design Week (2010) Profile: Neville Brody. Available at: http://www.designweek. co.uk/profile-neville-brody/3017972.article (accessed April 2012).

Dewey, J. (1979[1934]) Art as Experience. New York: Paragon Books.

Eco, U. (1985) Innovation and repetition: Between modern and post-modern aesthetics. Daedelus 114: 161-184.

Elkins, J. (2009) Artists with PhDs: On the New Doctoral Degree in Studio Art. Washington DC: New Academia Publishing.

Ellis, J. (2002) Seeing Things. London: IB Tauris.

Facer, K. (2011) Learning Futures. London: Routledge.

Featherstone, M. (1991) Consumer Culture and Postmodernism. London: Sage. 
Flew, J. (2005) Creative economy. In: Hartley, J (ed.) Creative Industries. Oxford: Blackwell, 334-361.

Hartley, J. (2005) Creative Industries. Oxford: Blackwell.

Hesmondhalgh, D. (2007) The Culture Industries, 2nd edn. London: Sage.

Hesmondhalgh, D. (2010) User-generated content, free labour and the cultural industries. ephemera 10(3/4): 267-284. Available at: http://www. ephemeraweb.org/journal/10-3/10-3hesmondhalgh.pdf (accessed April 2012).

Hesmondhalgh, D. and Baker, S. (2011) Creative Labour. London: Routledge. Holland, P. (2000) The Television Handbook, 2nd edn. London: Routledge.

Jones, P. (2004) Raymond Williams's Sociology of Culture: A Critical Reconstruction. Basingstoke: Palgrave.

Lambie-Nairn, M. (1997) Brand Identity for Television. London: Phaidon.

Louridas, P. (1999) Design as bricolage: Anthropology meets design thinking. Design Studies 20(6): 517-535.

Lupton, E. (2008) Graphic Design: The New Basics. Princeton, NJ: Princeton Architectural Press.

McGuigan, J. (2004) Rethinking Cultural Policy. Maidenhead: Open University Press.

Merritt, D. (1987) Television Graphics from Pencil to Pixel. London: Trefoil.

Miege, B. (1989) The Capitalization of Cultural Production. Amsterdam: International General.

Murphie, A. and Potts, J. (2003) Culture and Technology. Basingstoke: Palgrave Macmillan.

Myerson, J. and Vickers, G. (2002) Rewind 40 Years of Design and Advertising. London: Phaidon.

Negus, K. and Pickering, M. (2004) Creativity, Communication and Cultural Value. London: Sage.

Pite, S. (2003) The Digital Designer. Clifton Park, NY: Delmar Cengage Learning.

Redbee (2011) Available at: http://www.redbeemedia.com/about-us/overview (accessed April 2012).

Rowe, C. (1978) Collage City. Boston, MA: MIT Press.

Schon, D. (1987) Educating the Reflective Practitioner. San Francisco: Jossey Bass.

Sullivan, G. (2010) Art Practice as Research: Inquiry into the Visual Arts, 2nd edn. London: Sage.

Sussman, G. (2002) The Political Economy of Television. In: Miller, T (ed.) Television Studies. London: BFI Publishing, 7-10.

Walker, J. (2010) Email interview by author on 4 December.

Wells, P. and Hardstaff, J. (2008) Re-imagining Animation: The Changing Face of the Moving Image. Lausanne: AVA Publishing.

Williams, R. (1981) Culture. London: Fontana Press.

Williams, R. (1983) Towards 2000. London: Chatto \& Windus. 
Woolman, M. (2005) Type in Motion 2. London: Thames \& Hudson.

Wormleighton, I. (2010) Recorded interview by author on 12 December.

\section{BIOGRAPHICAL NOTE}

IAIN MACDONALD is a Senior Lecturer in Graphic Design and Motion Graphics at Edinburgh Napier University. He began his career as a television graphic designer at BBC TV Centre (1987-1996) before leaving to direct commercials through The Moving Picture Company. Between 2002-2009 he regularly taught motion graphics at Ravensbourne alongside other BBC alumini. Address: Edinburgh Napier University, Colinton Road, Edinburgh, Scotland EH105DT. [email: i.macdonald@napier.ac.uk] 